Nadine Atallah*

\title{
Modernism, Feminism and Science Fiction: Words as Silence, Language as Rhymes by Marwa Arsanios
}

DOI 10.1515/asia-2016-0030

Abstract: Words as Silence, Language as Rhymes is an artist book published in 2012 by Lebanese contemporary artist Marwa Arsanios, included in her Al-Hilal project (2011-ongoing). This project is based on an examination of the Egyptian cultural magazine Al-Hilal, and more particularly of two issues dating back to Nasser's presidency. These praised Nasser's ideology of Arab socialism and nationalism by highlighting technological and scientific innovations, social progress and women's emancipation. More than half a century later, after the failure of Nasser's policy and ideology, Words as Silence, Language as Rhymes analyses the rhetoric of modernism and its promises in the magazine. It takes a particular interest in the expression of Egypt's dream of space conquest, and in the representation of women, and more particularly of female Algerian freedom fighters. By re-engaging and manipulating Al-Hilal's textual and visual language, Arsanios plays with a multiplicity of temporal layers and uses the prospective potentialities of science fiction to re-imagine the modernist ideals and assert the importance of a utopian thought for the present. This article invokes Svetlana Boym's concepts of off-modernism and nostalgia to consider Words as Silence, Language as Rhymes as a feminist historiographical critique of modernism as conveyed by Al-Hilal.

Keywords: Marwa Arsanios, Al-Hilal, contemporary art, off-modernism, modern Egypt

*Corresponding author: Nadine Atallah, Université Paris 1 Panthéon-Sorbonne, Centre Panthéon, 12 place du Panthéon, 75231 Paris cedex 05, Paris, France.

E-mail: nadine.atallah@hotmail.fr 
The twentieth century began with a futuristic utopia and ended with nostalgia. Optimistic belief in the future was discarded like an outmoded spaceship sometime in the 1960s.

Svetlana Boym, The Future of Nostalgia ${ }^{1}$

In 2011, the Lebanese artist Marwa Arsanios (1978, Washington DC; lives and works in Beirut) came upon yellowed issues of the magazine Al-Hilal (The Crescent) dating back to the 1950-1960s. Launched in the late nineteenth century and still published today, Al-Hilal was one of the main publications of the Nahda, the Arab Renaissance, and it became very popular in left nationalist circles all over the Arab world. ${ }^{2}$ After the magazine was nationalized by Gamal Abdel Nasser, it contributed to forging and disseminating the official visions of Arab socialism and pan-Arabism; it was indeed taking an active part in achieving a crucial aim: the emergence of the independent and modern Egyptian nation.

Arsanios's Al-Hilal project (2011-ongoing) is an artistic exploration of the magazine and its political context, which is branching out to include performances, videos, installations, and an artist book published in 2012. This artist book features the pre-eminent issues developed all along the project, and is the main focus of this article. The whole project fits into a family of contemporary artworks referencing, scrutinizing and reformatting modernity and its ideological matching of modernism with a certain fascination for the past and its potentialities for the present, and even more so for the future. Unearthing and investigating the ruins of modernity is a recurrent process in Arsanios's work, which she had until then developed in particular in the field of architecture with All About Acapulco (2010-2011) and the Carlton Hotel project (2008), two investigations into the stories of modernist buildings in Lebanon. With the Al-Hilal project, Arsanios focuses on a different aspect: the language and rhetoric of modernism.

Presented by Arsanios as a "re-editing of an issue of Al-Hilal", ${ }^{3}$ the artist book Words as Silence, Language as Rhymes starts from the artist's contemporary examination of the words and images that contributed to shaping and conveying the message of Nasserism. It gathers texts and images collected and recreated from the issues dated November 1957 and January 1958, respectively dealing with female soldiers during the war of independence in Algeria, and Egypt's dream of space conquest. What the various topics developed by Al-Hilal during Nasser's presidency have in common is a future-oriented tone expressing an enthusiastic belief in a bright future for humanity. But even if the

1 Boym 2001: XIV.

2 See Al-Timawi 1992.

$3 \mathrm{http}$ //www.marwaarsanios.info/words-as-silence-language-as-rhymes-2011-2012.html $(11 / 28 / 2015)$. 
nationalization process was successfully conducted by Nasser ${ }^{4}$ and his policy led to major social changes, notably with the emergence of an Egyptian middleclass, the failure of pan-Arabism and Nasserism became obvious in the aftermath of the defeat of Egypt in the 1967 Six-Day War. Besides, going back to the specific topics of the November 1957 and January 1958 issues, one might note that both illustrate dreams that resulted in failures. Indeed, the Algerian female freedom fighters were never recognized as war heroines despite their key role in the country's independence ${ }^{5}$; similarly, Egypt never entered the international space race.

This article suggests considering Al-Hilal's predictions of a bright future as the expression of modernist desires, and to study Words as Silence, Language as Rhymes as a critical approach of modernism, defined as the driving principle of Al-Hilal and the heart of Nasserism as progressive policy and ideology. As part of the "re-editing" process, Arsanios replays or rather puts back into play the language of the magazine, in order to determine the status and temporalities of visions of a future that never came to be, and most probably never will. This formal experiment implies a strong political commitment: identifying the rhetoric of modernism and its participation in the writing of a progress-oriented history of modern Egypt - to be understood here as the Egypt of Nasser - and some of its violent consequences that affected women in particular, in order to counter them with alternative narratives. A noteworthy aspect of Nasser's modernist policy is indeed its conflicted relationship to feminism. ${ }^{6}$ Arab socialism encouraged women to participate in the public space and to engage in social activities, mainly as a new workforce, new consumers, and new citizens - for instance, they were granted the right to vote and the right to run for public office in 1956. But during the same decade, the independent feminist movements were banned, and activists were arrested or silenced, in favour of the establishment of a feminism influenced by the state. As a promoter of Nasserism, Al-Hilal obviously supported and contributed to circulating the state's interpretation of feminism. Therefore, the feminist perspective is significant in the critique of modernism and in the reflexion on historiography developed in Words as Silence, Language as Rhymes. In a conversation with Arsanios about the representations of the famous Algerian freedom fighter Jamila Bouhired in Al-Hilal,

4 Even though the independence of Egypt was officially proclaimed in 1922, British imperialist influence came to an end only after the nationalization of the Suez Canal by Nasser in 1956 and the ensuing failure of the British to re-establish lasting military control of the zone during the Suez Crisis.

5 Arsanios/Fraisse 2014.

6 On this point, see Bier 2011. 
the philosopher Geneviève Fraisse indeed raised this question: "When an image is produced, be it that of Nasserism with Jamila or other ones, the philosophical question of the writing of history comes up, i. e.: what is the point of engaging the issue of gender to write history."7

Rather than looking back on modernism as something belonging to the past, Arsanios directs a slanted look onto it. Thus this article proposes to understand her position as off-modernist, according to Svetlana Boym's definition of the term:

Instead of fast-changing prefixes - 'post,' 'anti,' 'neo,' 'trans,' and 'sub' - that suggest an implacable movement forward, against or beyond, and try desperately to be in, I propose to go off: 'off' as in 'off kilter,' 'off Broadway,' 'off the map,' or 'way off,' 'off-brand,' 'off the wall,' and occasionally 'off-color.' 'Off modern' is a detour into the unexplored potentials of the modern project. It recovers unforeseen pasts and ventures into the side alleys of modern history at the margins of error of major philosophical, economic, and technological narratives of modernization and progress. Critic and writer Viktor Shklovsky proposes the figure of the knight's move in chess that follows 'the tortured road of the brave,' preferring it to the master-slave dialectics of 'dutiful pawns and kings.' Oblique, diagonal, and zigzag moves reveal the play of human freedom vis-à-vis political teleologies and ideologies that follow suprahuman laws of the invisible hand of the market or of the march of progress. As we veer off the beaten track of dominant constructions of history, we have to proceed laterally, not literally, and discover the missed opportunities and roads not taken. ${ }^{8}$

It seems relevant to call in the concept of off-modernism to define Arsanios's critique of Al-Hilal, as it refuses any chronological positioning towards modernism - in that it perfectly meets the temporal ambiguities of Arsanios's project and prescribes instead a theoretical distance towards it in order to confront its dialectics, mainly characterized by a progress-oriented understanding of history. Thus, off-modernism bets on the possibility to build, on and out of modernism, a new future removed from its role as initiator of progress. In a way, offmodernism opens a door onto parallel dimensions, and Arsanios steps fully into them. The connexion between the two issues she selected, i. e. between anticolonial struggle on Earth and the desire of colonizing the moon, indeed suggest that one should consider the modernist ideals expressed in the magazine as belonging to science fiction: in the traditional literary and cinematographic meaning; as narratives influenced by the development of scientific

7 Arsanios/Fraisse 2014: 286, "quand on produit une image, que ce soit celle du nassérisme avec Jamila, ou d'autres, on croise la question, philosophique, de l'écriture de l'histoire, à savoir: à quoi cela sert de passer par la question des sexes pour écrire l'histoire.” All the translations were carried out by the author of this article.

On the issue of gender as an element in the production of history, see also Fraisse 2012.

8 Boym 2010. 
knowledge; and as social, political and economic impossibilities to be overcome. Supposing that Arsanios does not consider Al-Hilal's contents only as the remains of an ideology but as a "form-tool in the service of history," the aim of this article is to understand how sci-fi allows the imagining of alternative histories and alternative utopias, by recombining and reformatting modernist words and images. As part of this process, Arsanios explores more specifically the potentialities of the genre of feminist sci-fi, in order to examine and critique the modernist representation of women built up by Al-Hilal, and to respond to it.

After examining the contribution of Al-Hilal to the development of Egyptian, and to a greater extent pan-Arab modernist thought, this article ponders the stakes of a contemporary re-reading of the magazine, and its underlying nostalgia. The prospective potentialities of nostalgia will be discussed in order to expose and examine the multiple temporal layers composing Arsanios's project, and the necessity to break through the barrier of time to unsettle the restrictive Western and masculine categories of modernism. Moving into fiction, and more precisely science fiction, seems an appropriate way for Arsanios to confront the unfulfilled promises of modernism and start writing alternative histories in which the Algerian women soldiers can fully establish their heroic status, and in which travelling to the moon becomes a real option and a form of absolute emancipation.

\section{Al-Hilal, a modernist magazine}

The message of Al-Hilal: serving the renaissance of thought in the Arab world. ${ }^{10}$

The motto of Al-Hilal: resurgence, innovation, and forging ahead. ${ }^{11}$

Featuring large at the bottom of the contents pages of the November 1957 and January 1958 issues, these two sentences state loud and clear the philosophy of Al-Hilal magazine, and reveal a consistency with the original intentions of its founder, Jurgi Zaydan (Beirut 1861-Cairo 1914), a novelist, editor and journalist who played a key role in the Nahda. Founded in 1892, Al-Hilal asserted itself from the beginning as a political magazine: "The magazine was political in the sense that it defended the project of a society that was open to external ideas,

9 Caillet 2013: 67, "une forme-outil au service de l'histoire."

10 Al-Hilal, November 1957/January 1958, "Risalat al-Hilal: khidmat al-nahda al-fikriyya fi al-‘alam al-‘arabi”, p. 4.

11 Al-Hilal, November 1957/January 1958, "Shi'r al-Hilal: al-tajdid wa-l-ibtikar wa-l-sayir ila al-amam”, p. 5. 
informed of its own culture and language, and whose objective, eventually, was to take its place as part of the alliance of the modern nations." ${ }^{12}$ Dealing mainly with literature, history, news and science, Zaydan's Al-Hilal played an active part in the definition of Egypt's early nationalist and modernist project. Under Nasser's presidency, Al-Hilal was nationalized as part of a general policy of nationalization of the press. In this way, the magazine became an instrument of the state and of Nasserist propaganda, and contributed to nation-building through social cohesion, by inciting the people of Egypt, and especially the emerging middle-class, to gather around a common way of thinking, a common way of life and common visions of progress. Very much like the ideology it publicized, the magazine was circulated beyond Egypt's borders and was notably popular in Lebanese left nationalist circles.

The issues selected by Arsanios date back to Nasser's time and point up recurrent themes of modernism from all over the world: the emancipation of women and the faith in technological and scientific progress. "The Heroic Algerian Women”, dated November 1957, focuses on female soldiers during the war of independence in Algeria, while "The Moon Epoch", dated January 1958, is a special issue dedicated to the desire of Egypt to join the international space race. "I was attracted by these two issues as they are published within the lapse of two months, and it was striking how they connected in terms of colonial impulse. The end of colonialism and empires on earth was the beginning of realizing the impulse of colonising the moon," 13 highlights Arsanios. This symmetrical dynamic with respect to colonization suggests a distinction between history on the one hand, and pure dreams and desires on the other: if the November 1957 issue clearly supported the Algerian war of independence through the promotion of its women fighters - which is not surprising since Egypt was providing the Algerian National Liberation Front (NLF) with funding and weapons - the notion of an Egyptian space programme was total speculation in 1958, as planning for the country's first space programmes only started seriously in 1967, and was implemented in the 1990s. But as a symbol of modernism, development and national superiority, the idea of conquering the outer space soon gained ground in the field of fiction: "Men of letters outdistanced the scientists to the planets" ${ }^{\text {14 }}$ as an article from the January 1958

12 Dupont 2006: 209, "Politique, la revue l'était au sens où elle défendait le projet d'une société ouverte sur l'extérieur, instruite de sa culture et de sa langue, et dont l'objectif, à terme, était de prendre sa place dans le concert des nations modernes."

13 Arsanios 2012: n.p. Any occasional typographical, language or spelling mistakes in the original artist book have been deliberately kept in all the quotations.

14 Al-Hilal, January 1958, "Udaba' sabaqu al-'ulama' ila al-kawakib." 


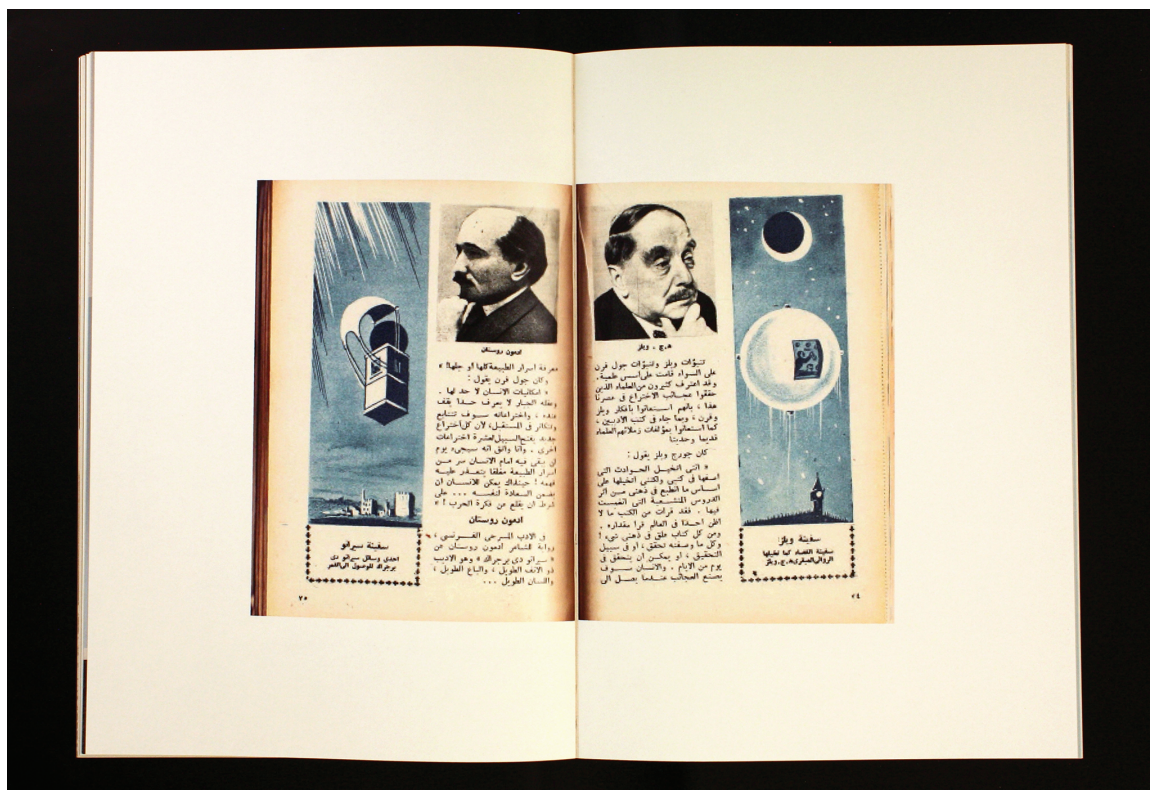

Figure 1: Reproduction of a double-page spread from the article "Men of Letters Outdistanced the Scientists to the Planets", Al-Hilal, January 1958. On the right: H.G. Wells. On the left: Edmond Rostand.

Source: Marwa Arsanios, Words as Silence, Language as Rhymes, 2012, $270 \times 190 \mathrm{~mm}$ (closed), n.p., (c) Marwa Arsanios. Courtesy of the artist.

issue states (Figure 1). And precisely, this issue dedicates many pages to sci-fi and includes translations of excerpts of books by H. G. Wells, Frederic Brown and Robert Heinlein. Even its supposedly scientific contents elaborate upon a hypothesis that may sound amusing if not absurd, like "To Whom Belongs the Moon and Which Laws Rule its Inhabitants?"15

Combining literary fictions and news about political and social facts as well, the November 1957 issue shows strong support for the NLF's struggle through propagandist articles such as "The Philosophy of Strength Created a Nation"16 and "The Heroic Algerian Women". ${ }^{17}$ The cover showing the portrait of a woman an Algerian fighter carrying a gun - is typical of the magazine's collection of the 1950-1960s (Figure 2). “At first, I was surprised by the covers of the magazine,

15 Al-Hilal, January 1958, "Li-man al-qamar wa-ayya qawanin tahkum sukkanaha?" transcribed under the title "Laws/Wars" in Arsanios 2012: n.p.

16 Al-Hilal, November 1957, "Falsafat al-quwwa khalaqat umma."

17 Al-Hilal, November 1957, “Al-jaza’iriyya al-batala.” 


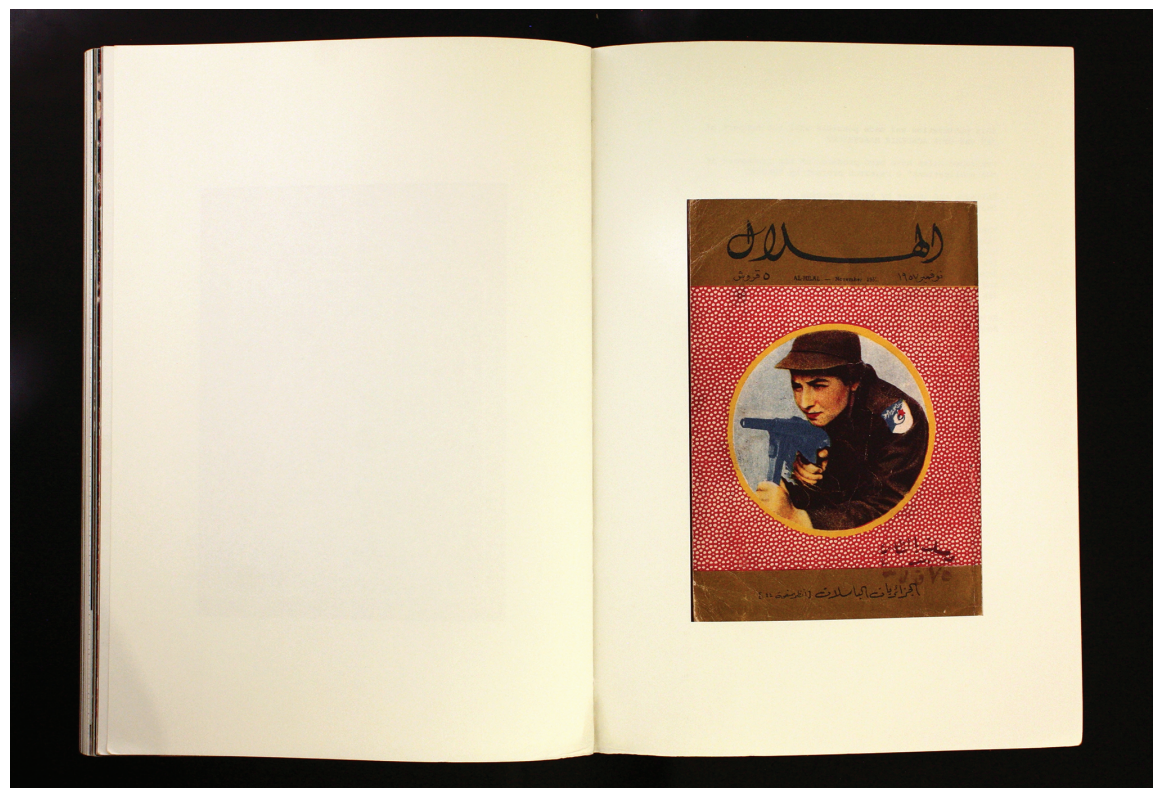

Figure 2: Reproduction of the cover of Al-Hilal, November 1957, "The Heroic Algerian Women." Source: Marwa Arsanios, Words as Silence, Language as Rhymes, 2012, $270 \times 190 \mathrm{~mm}$ (closed), n.p., (c) Marwa Arsanios. Courtesy of the artist.

struck by the overwhelming presence of women on them,"18 says Rasha AlAtrash, a journalist and writer invited by Arsanios to give a talk about the representation of women in Al-Hilal, which is transcribed in the artist book. The preponderance of women on the magazine's covers, but also in the articles, suggests the important role played by women in the social and political project of modernist Egypt. Actually, the issue of women's emancipation and agency is a leitmotiv of modernist programmes, and Al-Hilal takes them into account both as a factor of modernization and as readers of the magazine. This modern definition of women as new consumers is illustrated by the appearance of richly illustrated sections dedicated to fashion, beauty and domestic life in the 1950s. Besides, the magazine conveyed a certain idea of feminism sponsored by the state and particularly exemplified by Bint Al-Shati', real name 'Aisha 'Abd al-Rahman, who was the only regular female columnist and the author of an article in the two issues studied by Arsanios. Her texts interweave progressive ideas on how to dress and the right to work for instance, with more conservative ones especially in regard to religion.

18 Al-Atrash 2012: n.p. 


\section{Rereading Al-Hilal: from disillusionment to nostalgia}

Some sixty years after the publication of these contents, Arsanios invited former readers of Al-Hilal to take part in an engaging workshop:

I invited people who were familiar with the magazine itself and with this period as well, to take a few issues and reread and reinterpret them and say how they regarded them today. A lot of these people were coming from a left nationalist background and they had shifted into becoming more right-wing free-market liberals with years and experiences of disappointment; they had become hostile to this Nasserist history, refuting it and totally taking on the liberal discourse. ${ }^{19}$

As she observes that the former readers of the magazine have become vehement opponents of the ideologies that used to be theirs, Arsanios collides with the reality of her time. Although she never went through the moments of belief and disillusionment experienced in the late 1960s by Nasser's followers, she perceives these feelings after she met and discussed with them. "I also realized how sexist they were," says Arsanios, when the men participating in the workshop told her that no woman was capable of having an intellectual reflexion on Nasserism. ${ }^{20}$ Their attitude arouses the artist's anger, and consequently her own disillusionment overrides that of the former readers. Then, she decides, as a starting point for her artistic project, to engage in an ideological - but not only ideological - struggle against them.

You need to use their own language to fight them. But it is actually a language that they have rejected, and they have rejected it for a reason. So I can tell them 'I know what you were reading, and I know where you are coming from, and I will take it and use it for myself to fight against you. ${ }^{21}$

The assumption underlying Arsanios's words is interesting: she hypothesizes that it is possible to approach a language as a tool box in which one may dig and pick up words and images which may be combined, unassembled, reused and adapted to another historical and social context, so as to build weapons and fight for a space to imagine other utopias. Arsanios's intention indeed is far from trying to revive Nasserism: she plans to re-enact and rewrite the language of the magazine to reassess and reengage its potentialities in the present. Her position

19 Interview with Marwa Arsanios by the author at the artist's studio in Beirut (13 Sept. 2015, unpublished). From now on, the references to the interview will be cited as Arsanios/Atallah 2015. 20 Arsanios/Atallah 2015.

21 Arsanios/Atallah 2015. 
in regard to Nasserism can be compared to that of post-1989 artists from Eastern Europe in relation to the Soviet past: just like them, she responds to "the sense of urgency in relation to the importance of a utopian thought for the present"22 according to Claire Bishop's words.

This ubiquitous reorientation (and this more and more widespread glorification) of twentieth-century utopianism can be considered as a consequence of the convergence of the new digital technologies and a post-political consensus that smothers all opposition, and dismisses any form of militant criticism as outdated and archaic. The result of this is a return of contemporary art to artistic and architectural projects from previous times, in place of political commitment, and often under cover of utopianism. This substitution moreover serves as nostalgia for a time in which political convictions were still sincerely felt. $^{23}$

Bishop invokes the concept of nostalgia as defined by Svetlana Boym: it is not to be understood as a retrospective emotion, but as a prospective one that takes roots in the needs of the present and the necessity to affect the realities of the future. Nostalgia, says Boym, is "for the unrealized dreams of the past and visions of the future that became obsolete. The history of nostalgia might allow us to look back at modern history not solely searching for newness and technological progress but for unrealized possibilities, unpredictable turns and crossroads." 24 As such, nostalgia is a driving force of off-modernism serving the critical reflection on the modern condition and the affirmation "that history is never over, nor resolved."25

Thus the artist book Words as Silence. Language as Rhymes, subtitled Short Stories and Other Words on Paper, is an attempt to rewrite not the modernist ideology itself but rather the words and images through which it came to us, considering the magazine in its materiality. The cover of the artist book draws attention as it is entirely white, with the exception of the title and subtitle written

22 Bishop 2014: 48, "le sentiment d'urgence par rapport aux enjeux d'une pensée utopiste pour le présent.” Bishop notably analyses the works of Deimantas Narkevičius (Lithuania), Anri Sala (Albania) and Dan Perjovschi (Romania).

23 Bishop 2014: 47, “Cette réorientation omniprésente (et cette glorification de plus en plus généralisée) de l'utopisme du XXe siècle peut être considérée comme une conséquence de la convergence entre les nouvelles technologies numériques et un consensus postpolitique qui suffoque l'opposition, rendant toute forme de critique militante dépassée et archaïque. En résulte un retour de l'art contemporain à des projets artistiques et architecturaux d'époques antérieures, en lieu et place d'engagement politique, et souvent sous couvert d'utopisme. Cette substitution sert par ailleurs de nostalgie d'une époque durant laquelle les convictions politiques étaient encore sincèrement ressenties.” (My emphasis).

24 Boym 2001: XVI.

25 Caillet 2013: 73, “l'Histoire n'est jamais ni révolue, ni résolue.” 


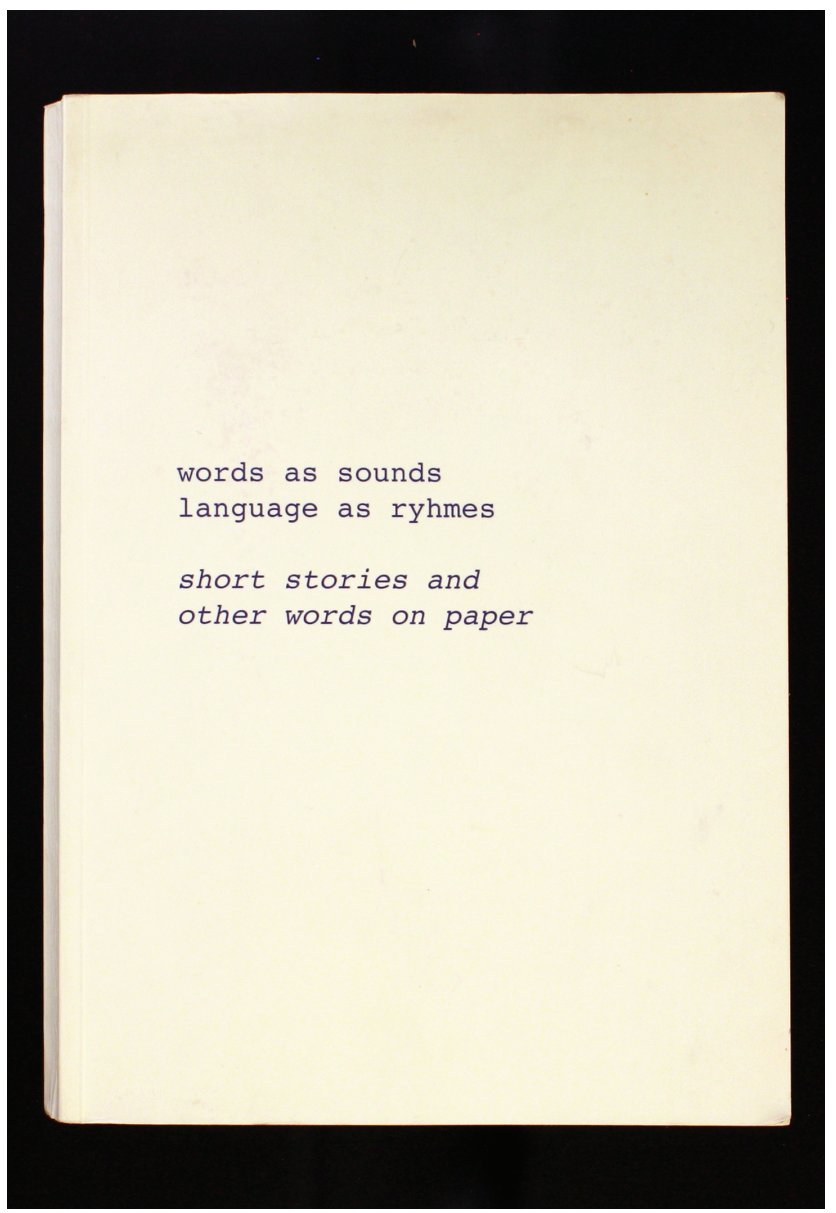

Figure 3: Cover of the artist book.

Source: Marwa Arsanios, Words as Silence, Language as Rhymes, 2012, $270 \times 190 \mathrm{~mm}$ (closed), n.p., (C) Marwa Arsanios. Courtesy of the artist.

with no capital letters in a blue monospace typeface characteristic of newspapers and used for all the textual contents inside the book (Figure 3). The original title, as it appears on the book's cover, is Words as Sounds, Language as Rhymes, later significantly changed by the artist to Words as Silence, Language as Rhymes. ${ }^{26}$

26 Marwa Arsanios confirmed this change of title during the interview (Arsanios/Atallah 2015), and it also appears on the artist's website: http://www.marwaarsanios.info/words-as-silencelanguage-as-rhymes--2011-2012.html (11/28/2015). 
A spelling mistake in the word "rhymes" (written "ryhmes") is also noteworthy the misspellings and language mistakes are numerous throughout the book, and contribute to its documentary and archival aspect. Most of the pages are taken up by images, and even most of the texts are treated like images: reproductions of pages from $\mathrm{Al}$-Hilal, pictures of handwritten notes by the artist, and superimposition of text and images. The visual contents are varied and include literal reproductions of material published in Al-Hilal - mainly photographs; collages made from elements taken from the magazine (Figure 4); pictures of some of Arsanios's works that constitute the Al-Hilal project; and many blank pages recalling the book's cover, as well as monochrome pages using colours often found in the magazine - including various shades of blue, yellow, and black. These monochrome pages split into two categories: those fully printed with one colour, and those showing photographs of coloured sheets of paper sometimes torn up, layered or rumpled (Figure 5). The white and monochrome pages participate in creating wide margins, spaces of silence recalling the title and determining the rhythm of the whole book. In a similar way, important margins are often saved, especially around the images and the reproductions of pages from Al-Hilal. Words

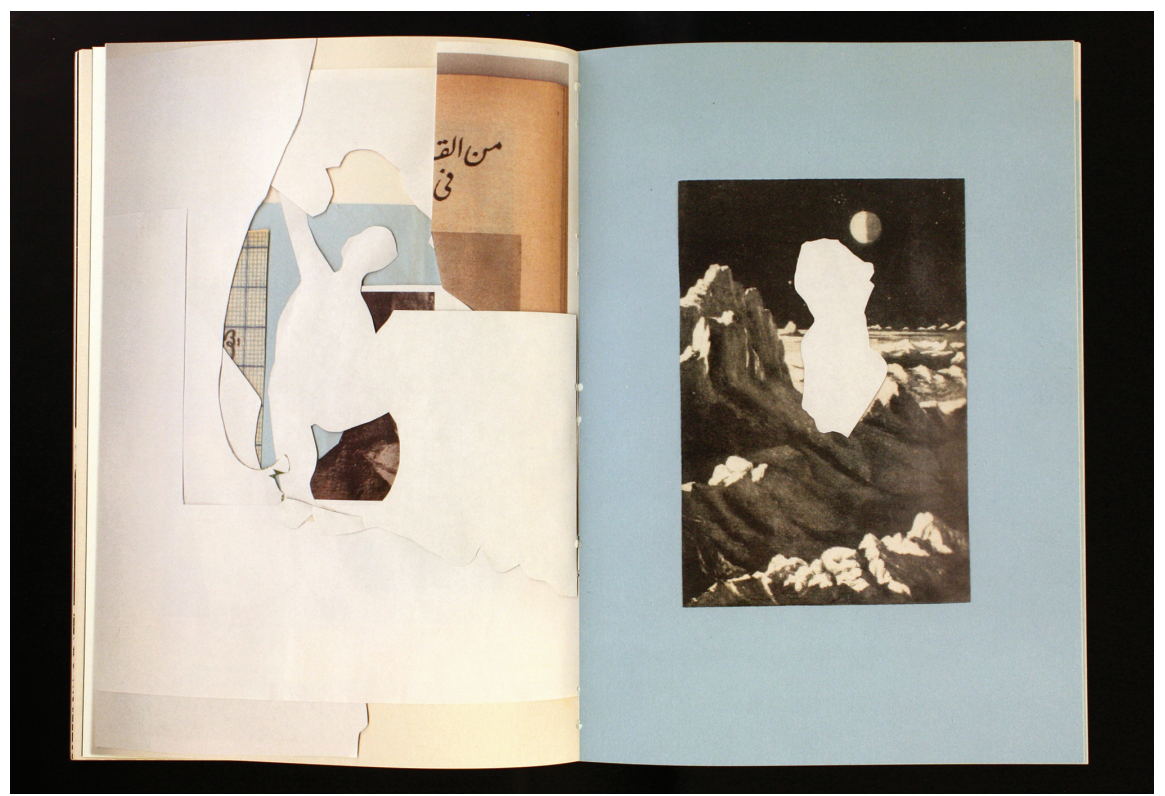

Figure 4: Example of a collage made with elements from Al-Hilal.

Source: Marwa Arsanios, Words as Silence, Language as Rhymes, 2012, $270 \times 190 \mathrm{~mm}$ (closed), n.p., (C) Marwa Arsanios. Courtesy of the artist. 


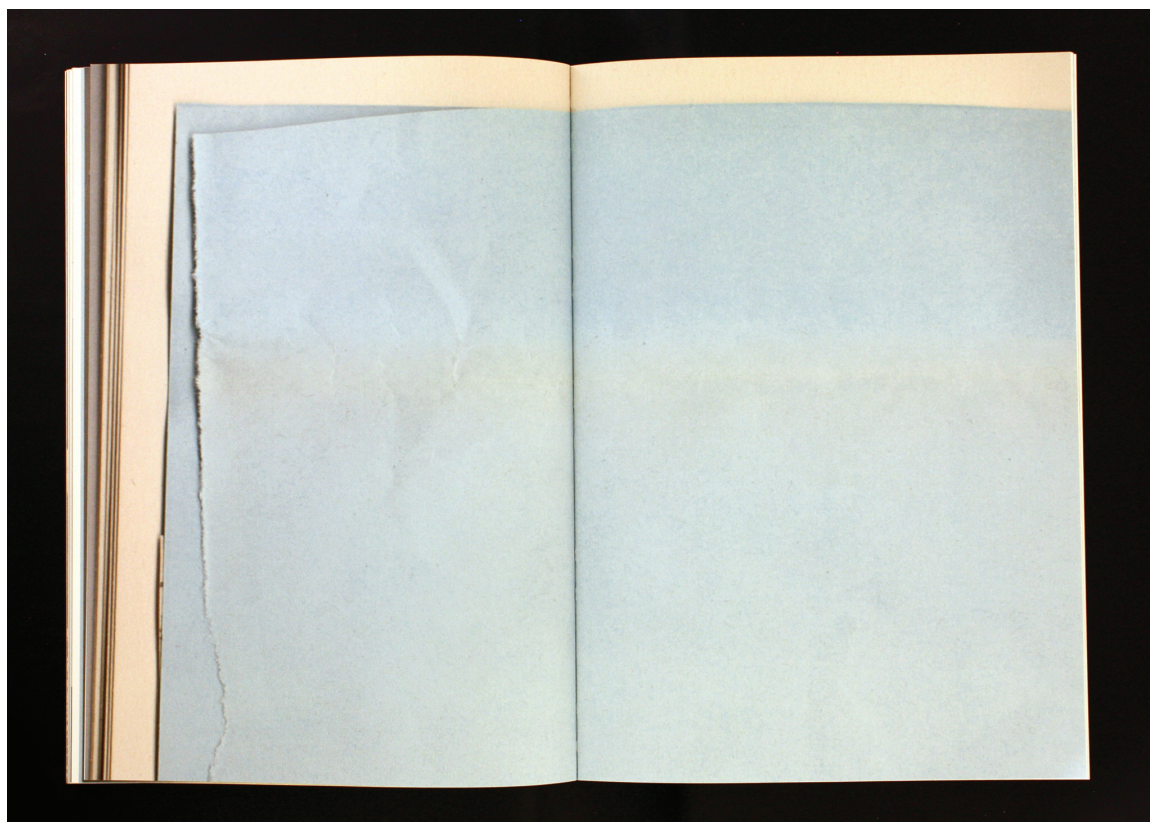

Figure 5: Composition with blank sheets.

Source: Marwa Arsanios, Words as Silence, Language as Rhymes, 2012, $270 \times 190 \mathrm{~mm}$ (closed), n.p., (c) Marwa Arsanios. Courtesy of the artist.

as Silence, Language as Rhymes uses the margins of Al-Hilal as a vacant space where it is possible to imagine new contents and reorient the actual ones. "Like harsh teachers when reading the writings of [their] literary predecessors," ${ }^{27}$ the contributors of the artist book, with Arsanios taking the lead, endeavour to revise and correct Al-Hilal's contents, and through them history, or, more precisely, the way it has been written.

The texts collected in Words as Silence, Language as Rhymes include translations of articles taken from the issues of November 1957 and January 1958, and copies of the original Arabic publications; essays by invited scholars and thinkers resulting from talks given at 98weeks, a platform of research cofounded by Arsanios in Beirut ${ }^{28}$; notes from discussions the artist had with a friend that freely bring together thoughts on particular topics; fictions written

27 Daoud 2012: n.p.

28 Founded in 2007 by Marwa and Mirene Arsanios, 98weeks is an artist-run organization and space, located in the neighbourhood of Mar Mkhael in Beirut. Its programme focuses on a different topic every ninety-eight weeks, and encourages collaborative practices. It includes 


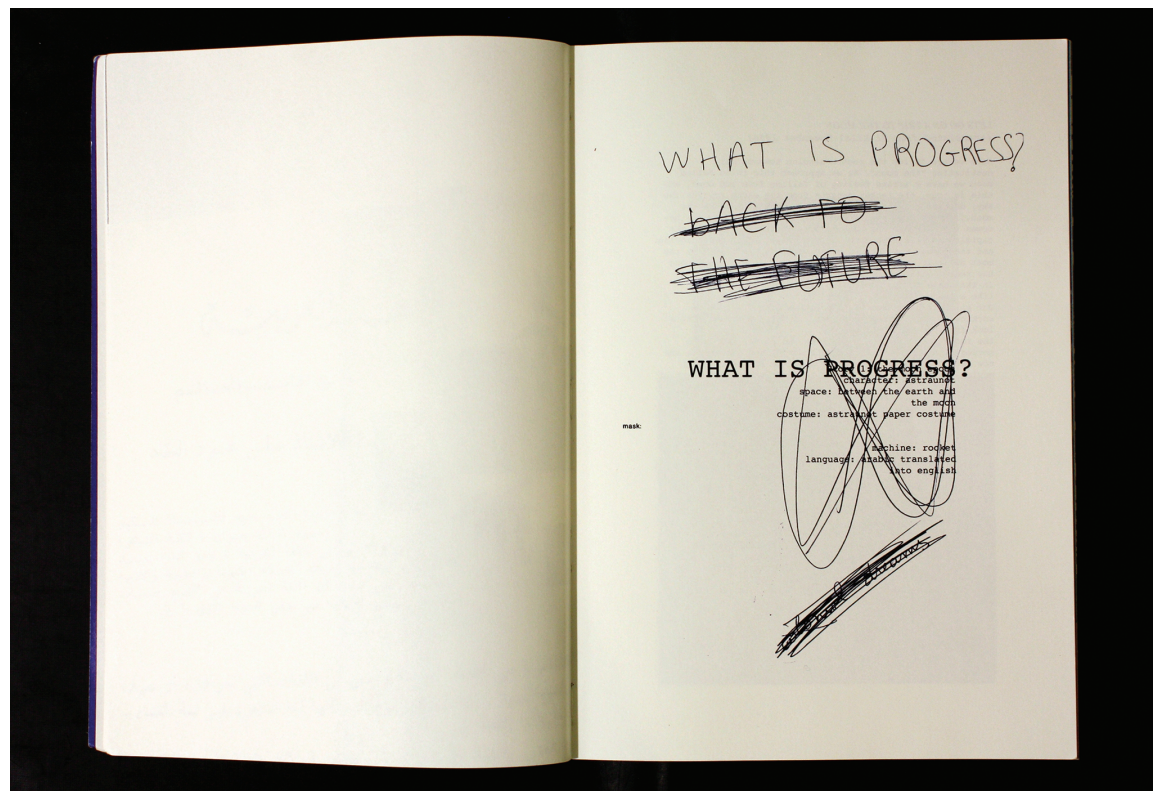

Figure 6: Title page of the chapter "What is Progress?"

Source: Marwa Arsanios, Words as Silence, Language as Rhymes, 2012, $270 \times 190 \mathrm{~mm}$ (closed), n.p., (c) Marwa Arsanios. Courtesy of the artist.

by her; and a poem by Iraqi modernist poetess Nazek Al-Malaika ${ }^{29}$ translated from Al-Hilal, February 1957. The fact that most of the authors included in the artist book are females constitutes a major move away from Al-Hilal. Five chapters structure the development of the book: "What is Progress?", focusing on the special issue of January 1958 (Figure 6); "Speaking Desire", which reflects on the process of re-enacting the language of Al-Hilal; "Should Women Fight”, focusing on the issue of November 1957; "Women?”, pondering the importance of the representation of women in the magazine; "Three Characters Looking for a Story", the last of three short stories written by Arsanios and distributed in various chapters. The book alternates the use of three languages, Arabic, English and French, which are the three languages commonly used in Lebanon, and the three languages Arsanios speaks and thinks in. The mixing of the languages also emphasizes the combination of

talks, workshops, seminars, exhibitions and publications. For further information, see: http://www.98weeks.net (11/28/2015).

29 Nazek Al-Malaika (1923-2007) is considered to be the first, with Badr Shakir Al-Sayyab, to have introduced the free rhyme in Arabic poetry. 
original contents from the magazine with contemporary studies and interventions on them; thus creating a sense of temporal confusion.

\section{Desires: past, present and future}

Through the interrogations developed in the introduction of the artist book, Arsanios proposes to understand the ideology sustained by Al-Hilal as the expression of desires for modernization, and more precisely "desires made of paper". ${ }^{30}$ This phrase rightly suggests that the magazine is the physical medium through which desires could survive the failure of Nasserism; they were kept unspoiled by their materialization through language - and printing. "What time does to people it cannot do to words and texts," writes Hassan Daoud in the artist book; ${ }^{31}$ this seems true, especially when the words and texts in question fluctuate between past, present and future. Indeed, as obsolete wordings and images of the future, the desires expressed in Al-Hilal make past, present and future coincide in one historical moment. The overlapping multiple temporalities coexist rather than compete in the artist book. Arsanios explains:

In most of my works, past, present, and future collide in a single moment, or they come together in the same frame, scene, narrative or character. This is also a political position, in relation to a modernist project that conceived of time in a much more linear manner and also imposed a dominant idea of time, masculine time. These were the grand narratives of progress, but they also represented an exclusive temporality conceived of by the modernizing elite, for the modernizing elite. ${ }^{32}$

Indeed, as a contemporary exploration of modernism and modern historicity, Words as Silence. Language as Rhymes unsettles the traditional Western conception of a linear time punctuated by the immutable succession of past, present and future. Christine Ross analyses this phenomenon in her theoretical examination of temporal developments in contemporary artworks:

Contemporaneity here strives to transform modernity. It does so by instilling in the artwork contemporary experiences of temporal passing, of what philosopher Yulov Dolev has called 'the becoming present of future events, and then their becoming past' that confront the futurism of the modern regime of historicity - modernity's progress-oriented

30 Arsanios 2012: n.p.

31 Daoud 2012: n.p.

32 Bidoun Magazine 2014: 146. (My emphasis). 
articulation of past, present, and future, in which future is constituted through the devaluing of the past and the erasure of the present. ${ }^{33}$

In her statement, Arsanios also calls the linear conception of time "masculine time", in reference to the feminist philosopher Rosi Braidotti's theories about "the possibility of a specific women's time" ${ }^{34}$ defined by "a stolen present and a frozen past", and in which "the only possible source of inspiration is the future itself" ${ }^{35}$ Arsanios interprets Braidotti's idea: "[she is] not only thinking of futurity in a feminist manner. The very idea of the future becomes feminist, and feminism becomes intrinsically related to the potential for accomplishment in the future." 36 Thus, Arsanios's deconstruction of the temporal categories of modernity, as a political and a feminist position, implies a dynamic definition of the future. From a modernist perspective, the future is the destination of a progress-oriented history, but the fact that some promises of modernism were never fulfilled proved this hypothesis wrong. Consequently, it appears imperative to dismiss the future from its modernist role and consider it instead as "an active object of desire [that] propels us forth and motivates us to be active in the here and now", ${ }^{37}$ in other words to define it as a driving force for the present. Actually, reconsidering $\mathrm{Al}$ Hilal nowadays is not a search into the past; it is a reconsideration of possible futures to be implemented in the present. "'The becoming present of future events and then their becoming past' shifts into 'the becoming present of past events and then their becoming future'," continues Ross. The reorganization of time, or more precisely the revisiting of time and the resistance to its irreversibility is driven by nostalgia as "a yearning for a different time [...]. In a broader sense, nostalgia is a rebellion against the modern idea of time, the time of history and progress, ${ }^{38}$ and to that extent it favours the expression of desire, which, in contrast to progress, is not necessarily orientated towards the future as an ideal end. Nostalgic emotion encourages the equalization and even the hybridization of past, present and future. Boym makes it explicit: "The nostalgic feels stifled within the conventional confines of time;"”39 therefore it becomes necessary to break through its barriers. Could there be a better way to break free from the confines of time than by moving into the field of sci-fi, an open realm of the possible where temporal crossing is common practice?

33 Ross 2013: 5.

34 Braidotti 2009: 4.

35 Braidotti 2009: 7.

36 Bidoun Magazine 2014: 147.

37 Braidotti 2009: 8.

38 Boym 2001: XV.

39 Boym 2001: XIV. 


\section{The historiographical potential of science fiction}

As mentioned before, Al-Hilal is well-known for associating literary fictions and scientific essays with the idea that both types of writing can help understand the problems of an age; and obviously this operational mode is particularly efficient when it comes to speaking about conquering the moon. The mixing of the genres intensifies the ambiguity of Al-Hilal's archives as historical documents; in fact the magazine relates "a dual history of illusion and of actual practices". 40 "I started looking at history as something that could be fictional, and at fictions as something that could be historical," says Arsanios, reaching the conclusion that "fictions were another way to open utopia, and reopen a space for thinking about utopia". ${ }^{41,42}$ The artist book actually includes three short stories that use the codes and settings of sci-fi, written by the artist herself and gathered under the title "Three Characters Looking for a Story". The reference to sci-fi is particularly meaningful as part of Arsanios's project to unsettle the categories of modernism: in the 1950s, after the use of atomic bombs raised awareness that scientific progress could be dangerous and lead to the most atrocious consequences, sci-fi authors seriously criticized the notion of progress. ${ }^{43}$ The period saw the emergence of alternative history, or "allohistory", a sci-fi sub-genre operating through uchronia, in which history unfolds differently from how it did in reality. In her study of Arab sci-fi, Ada Barbaro explains the interest of Arab writers in the genre of alternative history, literally translated in Arabic as "altarikh al-badil":

The narrative expedient consisting in imagining alternative histories from the lived ones is very often used for rereading dark events from the past, reinterpreting phenomena that already occurred and foreseeing possible disruptions, thanks to the possibility of

40 Boym 2001: XVIII.

41 Arsanios/Atallah 2015.

42 It seems relevant to mention here a similar endeavour by Lebanese artists Joana Hadjithomas and Khalil Joreige: The Lebanese Rocket Society. This multidisciplinary project includes a film (2012) which elaborates on the attempts of a group of students to launch rockets into the Lebanese sky in the 1960s. Recounting the major steps of this adventure while pondering the reasons why it did not lead to the development of a proper Lebanese space programme, The Lebanese Rocket Society mingles documentary and science fiction. It proposes to imagine what the future could have been if the students' research, as "a progressive and modernist utopia that promised to transform [the Arab] region and the world", had actually been developed. See http://www.e-flux. com/journal/on-the-lebanese-rocket-society-2/ (01/20/2016).

43 On this matter see Dick 1995. 
rebuilding everything that has been borne out before. In such a context, it is of course possible to make out which imaginary perspectives present themselves to the writers who, precisely in this case, can use writing as a tool for social analysis, restoring one of the main prerogatives usually associated with the most important sci-fi production. ${ }^{44}$

Sci-fi, indeed, has an important subversive power associated with a capacity to speculate upon possible other courses of history under cover of imagination. It thus proves to be an ideal locus of rectification of historical disillusionments. Therefore it is not surprising that Al-Hilal resorted to this genre to serve nationalist propaganda in "The Moon Epoch" in $1958 .{ }^{45}$

The Arabic translation of "science fiction" as "al-khayal al-ilmi", which means "scientific imagination", clearly reveals the origins of sci-fi as a genre based on science and on speculation on its potential development. Amongst the many scientific sections of Al-Hilal, Arsanios identified "The News of Tomorrow and After Tomorrow", ${ }^{46}$ hypothesizing on the year 2000 and the sum of revolutionary advances it would bring. "Read the Titles", which refers to both a poem and a song inside the artist book, is a collection of titles taken from these scientific sections, more or less based on real facts: some present medical discoveries, others speculate on the invention of new machines, and others again are far-fetched visions of innovations to come. Put together, these titles give body to Dadaist-like compositions:

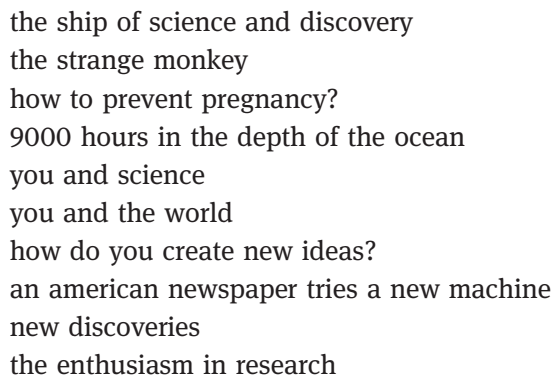

44 Barbaro 2013: 24, "L'espediente narrativo di immaginare storie alternative a quelle vissute serve molto spesso a rileggere oscuri avvenimenti del passato, reinterpretare fenomeni già avvenuti e prevedere possibili stravolgimenti, grazie alla possibilità di ricostruire quanto già verificatosi. In un contesto del genere, si possono naturalmente intravedere quali prospettive immaginative vengano offerte agli scrittori che, proprio in questo caso, possono utilizzare la scrittura come strumento di analisi sociale, riabilitando una delle principali prerogative solitamento associate alla più interessante produzione fantascientifica.”

45 While discussing the complexity of clearly identifying the origins of Arab sci-fi, Barbaro states that it first appeared in Egypt in the late 1940s with the writer Nihad Sharif.

46 Arsanios 2012: n.p. 
glasses that light at night

a revolution in the shoe industry (Figure 7$).{ }^{47}$

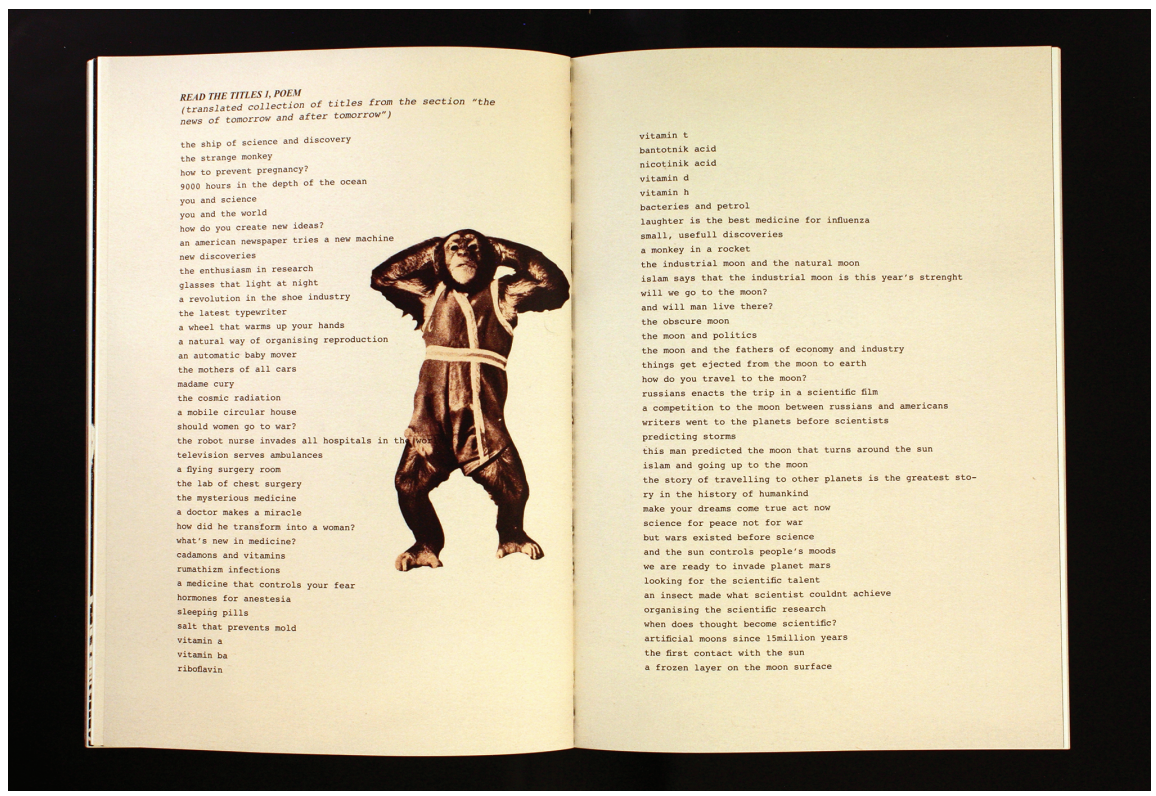

Figure 7: "Read the Titles 1, Poem".

Source: Marwa Arsanios, Words as Silence, Language as Rhymes, 2012, 270 ×190 mm (closed), n.p., (c) Marwa Arsanios. Courtesy of the artist.

These texts were also used for a performance Arsanios originally gave in 2011 at the Villa Romana in Florence: wearing a costume made of strips of the magazine, the artist recited the succession of titles in a monotone hypnotic voice, expressing the aspirations and anxieties of modern man. These words, with no identified author and no identified addressee, resonate like a mystical visionary incantation, and give sense to the second part of the artist book's title Language as Rhymes. The artist's costume, materializing her speech, also suggests that the magazine acquires more substance when being used as a dressmaking material (Figure 8). Here, one may recall that costume and custom are essentially the same word: both come from the old French costume, which used to refer to a set of distinctive features of a time, a social group, or a genre, that are most often immediately perceptible or related to

47 Arsanios 2012: n.p., "Read the Titles 1, Poem” in the section "What is Progress". 


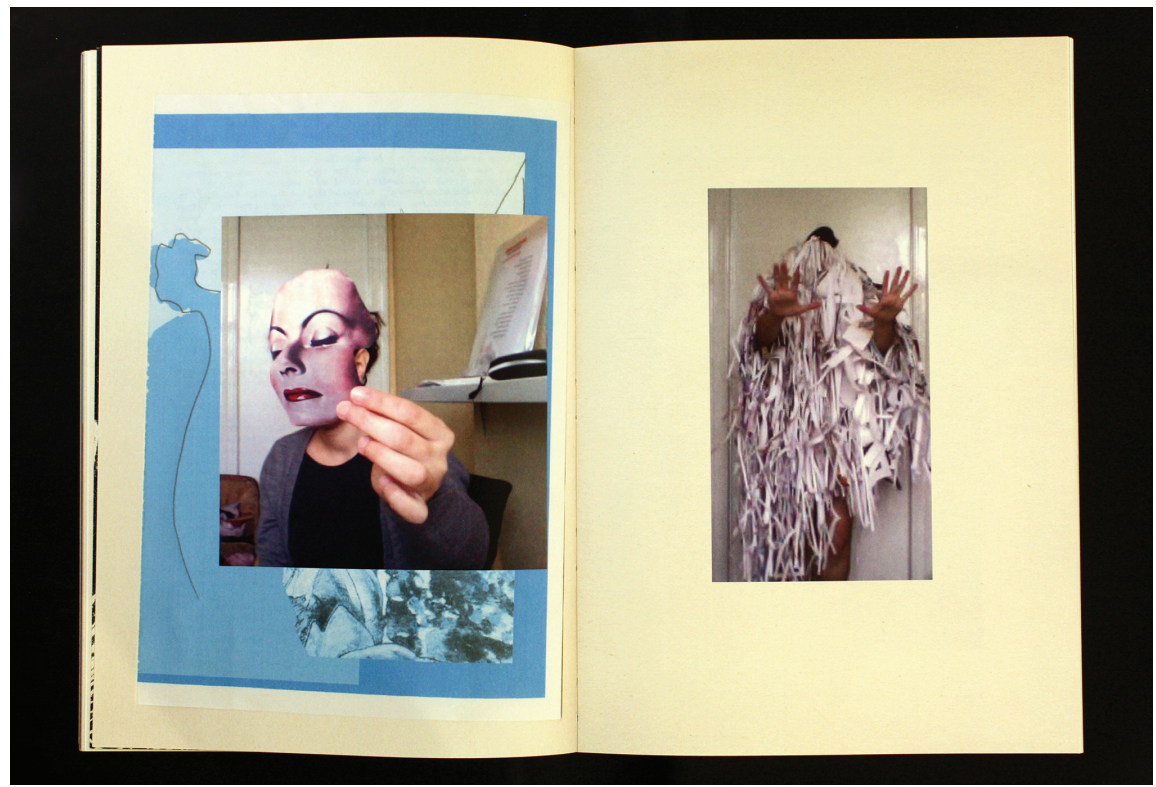

Figure 8: On the right: costume of the performance Read the Titles. On the left: collage. Source: Marwa Arsanios, Words as Silence, Language as Rhymes, 2012, $270 \times 190 \mathrm{~mm}$ (closed), n.p., () Marwa Arsanios. Courtesy of the artist.

appearance. Moreover, in the introduction of the artist book, Arsanios insists on the importance of the costume as a factor of emancipation:

Liberation comes with a new clothe and sometimes a new uniform, a new costume. In order to go to the moon we will need to wear a special costume. This costume is the only costume that will liberate us from planet earth and its laws. Costumes, masks and scripts will make of us new characters in a new story every time. ${ }^{48}$

Thus in a way, Arsanios offers to rethink the costume of modernity - in the archaic French meaning - by designing clothes to be worn by new modern characters. "If the story of the moon has its specialised technical costume, then the story of colonisation has also its uniform. [...] Two stories happening at the same time but in different spaces: Olga the astronaut was liberated by the moon, and Jamila the fighter was liberated by the military costume." ${ }^{49}$ In an interesting detour, Arsanios first determines the costumes, and then creates the characters

48 Arsanios 2012: n.p.

49 Arsanios 2012: n.p. 
of her fictions, those "Three Characters Looking for a Story", including two women, as well as a monkey which took part in the first rocket experiments. The two women were originally real characters: Olga is the artist's grandmother, who lived in Egypt during the era of Nasser and was a communist - she embodies "the image of someone that has not been able to emancipate herself because of a certain structure" 50 and who manages to flee to outer space; Jamila is Jamila Bouhired, who, as a woman and an Algerian freedom fighter, became a symbol of anti-colonialism and was often represented in the pages of Al-Hilal. The stories of Olga and Jamila are the artist's response to the topics of the November 1957 and January 1958 issues.

\section{Science fiction and the heroines of modernity}

In her aptly titled article "Science Fiction and the Heroines of Modernity", feminist sci-fi writer Elisabeth Vonarburg examines the way sci-fi relates to the world, compared to realist literature and fantasy: "The mode of sci-fi, and mine, somewhere in between, or rather in the margins of the other two, would be to appropriate what is, as the 'realists' do, but by deeply metamorphosing it - like the 'fantasy-makers.' And I believe it is also, I strongly believe it, the only way out for a woman." ${ }^{51}$ Sci-fi, she says, is in the margins, and as such it is often pejoratively considered as a "para-literary" 52 genre. But Vonarburg asserts that this marginality is, on the contrary, the basis for sci-fi's subversiveness: "Sci-fi's sideways position, whether claimed or imposed, is undeniably a space of freedom from normative literature." 53 And this is why she believes it is a genre that is very favourable to feminism, since it allows dealing “creatively with women's problems, not just reactively like mainstream literature does". ${ }^{4}$ Sci-fi and feminism share a common utopian drive: "SF has utopia for an ancestor and therefore invents other social models, as feminism itself must do."55 Furthermore,

50 Arsanios/Atallah 2015.

51 Vonarburg 1994: 457, "Le mode de la SF, et le mien, quelque part entre les deux, ou dans leurs marges respectives, serait de s'approprier ce qui est, comme les "réalistes », mais en le métamorphosant profondément - comme les 'fantastiqueurs'. Et il se trouve que c'est aussi, je le crois fermement, la seule issue possible pour une femme."

52 Vonarburg 1994: 454, "para-littéraire."

53 Vonarburg 1994: 454, "l'à-côté de la SF, revendiqué ou imposé, constitue indéniablement un espace de liberté par rapport à la littérature normative.”

54 Vonarburg 1994: 453 (from the abstract in English).

55 Vonarburg 1994: 453 (from the abstract in English). 
both bring together all the fields of knowledge and science in order to respond to major social issues. From her analysis of the representation of women in Al-Hilal, Al-Atrash precisely states that, in the magazine, "the women appear to jump between two fictions. [...] On the one hand, it's a historical fiction [...]. On the other hand, it's science fiction, [...] a fiction that was influenced by the development of sociological and psychological thought." 56 But social sciences here were used to legitimate a misogynistic form of language in disguise, as for instance in "Women with Blonde Hair", a supposedly scientific article penned by Dr. Amir Boqtar, demonstrating through the use of statistics that blonde women "are not competitive, frown for trivial reasons, are egotistical and antisocial." 57 While Al-Atrash invalidates such language by qualifying it as fictional and even science fictional, Arsanios reverses the trend and states loud and clear that fiction has a strong potential for impacting reality: "I don't believe that fiction is not effective. I don't believe that fiction is not political." ${ }^{\text {" }}$ Furthermore, she brings back together the two kinds of fiction identified by Al-Atrash, history and sci-fi, in one single movement: writing an alternative history in the form of feminist sci-fi short stories. Actually, feminist sci-fi is a genre Arsanios knows well, and which she explored on several occasions; for instance, it was the subject of her work A Platform for Reading Feminist Texts. ${ }^{59}$ Thus, more than "looking for a story", Arsanios's characters Olga and Jamila are looking for history, and more precisely for their own position in history.

The three short stories share one main focal point: the importance of speech: "The Moon, the Shoe" reports Olga's stream of consciousness while she is in the outer space with a team of astronauts; "Have you Ever Killed a Bear?" is a speech by Jamila including stage directions which indicate that the character speaking is in reality a performer embodying not only the real and historical Jamila, but also all the fictional Jamilas created by cinema; ${ }^{60}$ finally, "Olga, Jamila and Raul" relates the encounter between the two characters and their

\footnotetext{
56 Al-Atrash 2012: n.p.

57 Al-Atrash 2012: n.p.

58 Arsanios/Atallah 2015.

59 Presented at Kunsthaus Hamburg in 2015, the installation took the shape of a small blue stage on which texts by feminist sci-fi writers were gathered, and where a performer read excerpts from Donna Haraway's A Cyborg Manifesto (1985). A criticism of traditional notions of feminism, A Cyborg Manifesto ponders over the future of socialist feminism in the context of the early Reagan era in the US. It invokes the metaphor of a cyborg to refuse and move beyond the established and restrictive categories of gender, feminism, and politics.

60 This text is the first version of the script of the performance Have You Ever Killed a Bear or Becoming Jamila, from which Arsanios also made a video (2013-2014).
} 
conversation. ${ }^{61}$ At first, Arsanios seems to encourage considering speech as emancipating; she argues that, through speech, "an unseen political subject"62 can be transformed into a heroine. Incidentally, in 2013 she invited the Indian philosopher Nikita Dhawan, author of the essay Impossible Speech: On the Politics of Silence and Violence (2007), to give a talk on the radio. In order to discuss the dialectics of speech and silence, and the political stakes of each, Dhawan read Gayatri Chakravorty Spivak's Can the Subaltern Speak? (1988). ${ }^{63}$ This is quite striking when it comes to the character of Jamila, since Jamila Bouhired was famous for her silence. She refused to defend herself before the tribunal that was trying her for terrorism, and later refused to join the government of independent Algeria, and even to play her role in Gillo Pontecorvo's film La Bataille d'Alger (The Battle of Algiers) (1966). By contrast, she was the source of fantasies and fetishism like the female soldiers depicted in Al-Hilal (Figure 9),

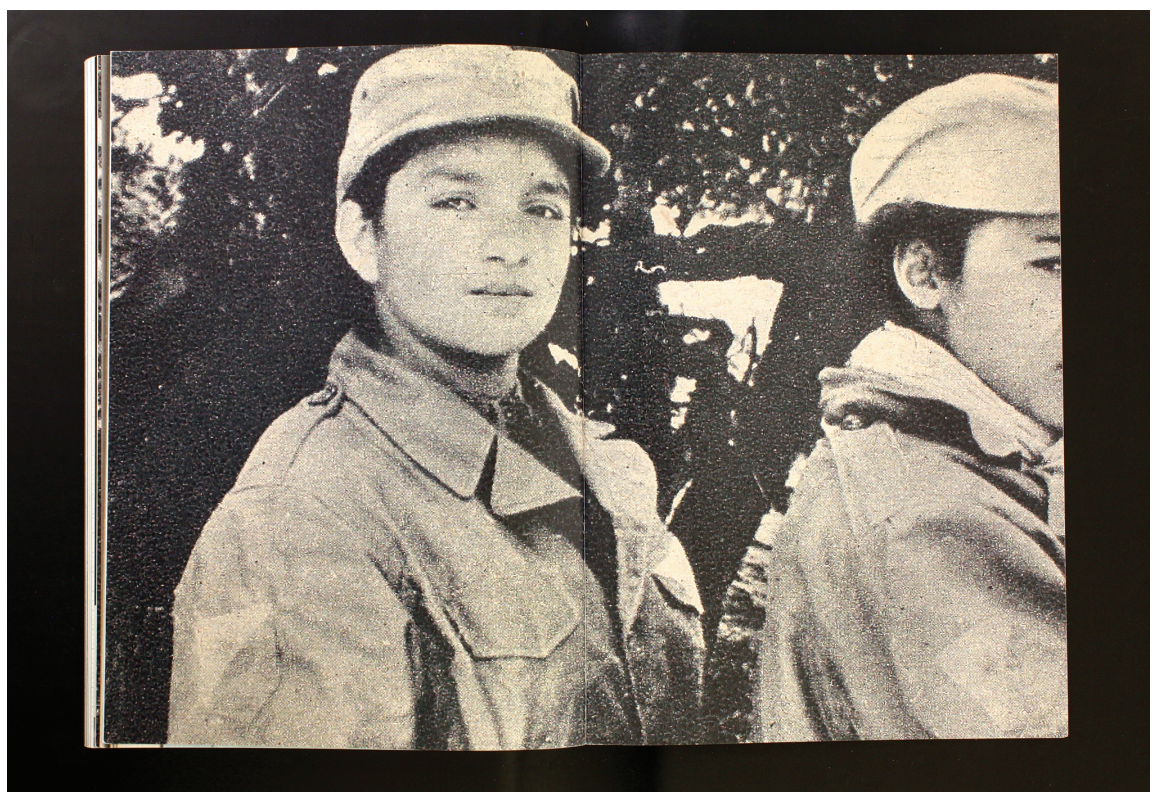

Figure 9: Algerian female soldiers.

Source: Marwa Arsanios, Words as Silence, Language as Rhymes, 2012, $270 \times 190 \mathrm{~mm}$ (closed), n.p., (c) Marwa Arsanios. Courtesy of the artist.

61 Raul only exists through the mentions Olga and Jamila make of him.

62 Bidoun Magazine 2014: 150.

63 Dhawan 2013. 
and the central protagonist of many anti-colonial texts and films like Jacques Vergès's manifesto Pour Djamila Bouhired (For Jamila Bouhired) and Youssef Chahine's Jamila al-Jaza'iriyya (Jamila, the Algerian) (1958). While critiquing this phenomenon, Arsanios's "Have You Ever Killed a Bear?” also puts words in Jamila's mouth: "I had to abuse her myself in order to critique those who abused her before," ${ }^{64}$ she explains. The abuse comes from the fact that "speaking means moving on to the side of images, of heroic, iconic images", ${ }^{65}$ as Fraisse makes clear. Breaking her silence takes Jamila out of history into images, or in other words out of action into representation. But Arsanios's endeavour is precisely to reconcile these two apparently contrary aspects, in accordance with her project of bringing together fiction and history. Indeed, sci-fi allows her to step into the territory of myths, of the founding narratives that are not recorded in history. As Jamila was dispossessed from speech, from a heroic position in history, Arsanios attempts to inscribe her in a new mythology. "As a woman, I need new versions of the existing myths, if not new myths!"66 Vonarburg stated to define one of the undertakings of feminist sci-fi. However, moving from writing an alternative history to writing an alternative mythology implies renouncing the official recording of the narratives produced, a radical position totally sustained by Arsanios when she declares: "We [the women] don't want to be in their [the men's] official history". ${ }^{67}$

In relation to the exclusion of the female soldiers from history, Fraisse refers to a "self-effacement of women as stakeholders of history". ${ }^{68}$ She means that women resolved by themselves not to demand historical recognition for their participation in the war: while they were fighting on the frontline, the other women got married and became mothers, i. e. they fulfilled their women's lives; therefore demanding a heroic status would mean renouncing any acceptable, or more precisely any comprehensible social position. By challenging the gender division of tasks and space, the female soldiers indeed became socially illegible, and silence seemed a necessary defence for them. In this way they exceeded the limits of language. ${ }^{69}$ In a similar way, Olga and Jamila, as sci-fi heroines of modernity, embody both the limits and dangers of

64 Arsanios/Atallah 2015.

65 Arsanios/Fraisse 2014: 285, “parler, c'est être déplacé du côté de l'image, de l'image héroïque, iconique".

66 Vonarburg 1994: 457, "en tant que femme, j'ai besoin d'autres versions des mythes existants, sinon de mythes nouveaux!”

67 Arsanios/Atallah 2015.

68 Arsanios/Fraisse 2014: 285, "auto-effacement des femmes comme actrices de l'Histoire."

69 Dhawan 2013. 
speech in the emancipation process, and the deficiency of the specific language of Al-Hilal, from which they were created. This might be why, in the end, Arsanios does not insist on allowing them to speak: she reaches the conclusion that language disallows as many things as it allows. In "The Moon, the Shoe”, Olga is constrained by her space suit. She appreciates it as the technical invention that allowed her to flee from Earth, as the vehicle of her liberation, but this costume also prevents the astronauts from hearing each other. Similarly, the conversation between Olga and Jamila is abruptly interrupted at the end of "Olga, Jamila and Raul", while they seem to be taking off towards new horizons:

\author{
Jamila: can you hear me? \\ Olga: yes but your voice is cutting \\ Jamila: my voice? \\ Olga: (she speaks in signs) \\ Jamila: (whispers) something might me happening with the wind \\ Olga: (mumbles) but, what if what broooole had no lennnnei \\ Jamila: vroooooook brook crook vroooook begggggg \\ Olga: makd vroook brooooook bwerk \\ Jamila: loooooooo ne vrooooook brooook \\ 38 miles above ground! $!^{70}$
}

\title{
6 The side alleys of modern historiography
}

Al-Hilal developed an original system of representation, which combines the expression of real facts and of dreams, encapsulating the Nasserist ideology. Continually fluctuating between science and fiction, the magazine carried promises that were never fulfilled. Its language is mainly characterized by its ambiguity: the expression of space conquest as an achievable aim contributed to the empowerment of the new Egyptian nation while it did not refer to any concrete initiative; at the same time, Al-Hilal was partly responsible for turning the Algerian female soldiers into icons, consequently preventing them from becoming heroines. More generally, it favoured the visibility of women while 
neglecting to defend their agency. Considering that the representations built by Al-Hilal durably and effectively impacted the writing of history, Words as Silence, Language as Rhymes endeavours to borrow the magazine's strategy of ambiguity in order to criticize and deliver a definition of modernism, as an ideology and a category that conditions a certain understanding of history. By moving "off” modernism, Arsanios reconciles history and fiction and resorts to the historiographical potential of sci-fi, associated with a strong belief in the political efficiency of fiction. In this way, she manages to counter the modern regime of historicity and to break free from a linear conception of the passing of time that imposes the future as an ideal and absolute end. Driven by a nostalgic positioning in relation to modernism, and by Braidotti's feminist conception of time, she replaces the notion of future with that of desire, which makes it possible to preserve a utopian drive for her project and to keep believing that fundamental political change is possible in our time. "I wanted to put the question of feminism today on the table, in a blunt manner, as a strategy to rethink politics in general, not only gender politics," 71 she says. Words as Silence, Language as Rhymes is indeed a deeply political project which arouses a complete rethinking of politics and its field of action, with an emphasis on the urgency of taking into account the issue of gender in any historiographical consideration.

When she moves from writing an alternative history to writing an alternative mythology, Arsanios ventures into "the side alleys" 72 of modern historiography, and of the historiography of modernism. That lateral move highlights her understanding of Al-Hilal's modernist language: rather than a political ideology rooted in a particular historical context, she approaches it as a collection of mythical narratives. This allows her to create new characters in new stories - those sci-fi heroines of modernity whose speeches express "the unexplored potential of the modern project", and whose silence challenges "the dominant constructions of history". ${ }^{73}$ Furthermore, by refusing to inscribe her own narratives in the official history, the artist rehabilitates and asserts the efficiency of marginality as the space of freedom and feminism, according to Vonarburg. Indeed, sci-fi, blank pages and silence become her tools for highlighting the failures of modernism, and what turns out to be a certain vacuity of its language.

Three years after the release of the artist book, in 2015, while carrying on with her examination of Al-Hilal, Arsanios radically concludes: "You feel that it is such

71 Bidoun Magazine 2014: 150.

72 Boym 2010.

73 Boym 2010. 


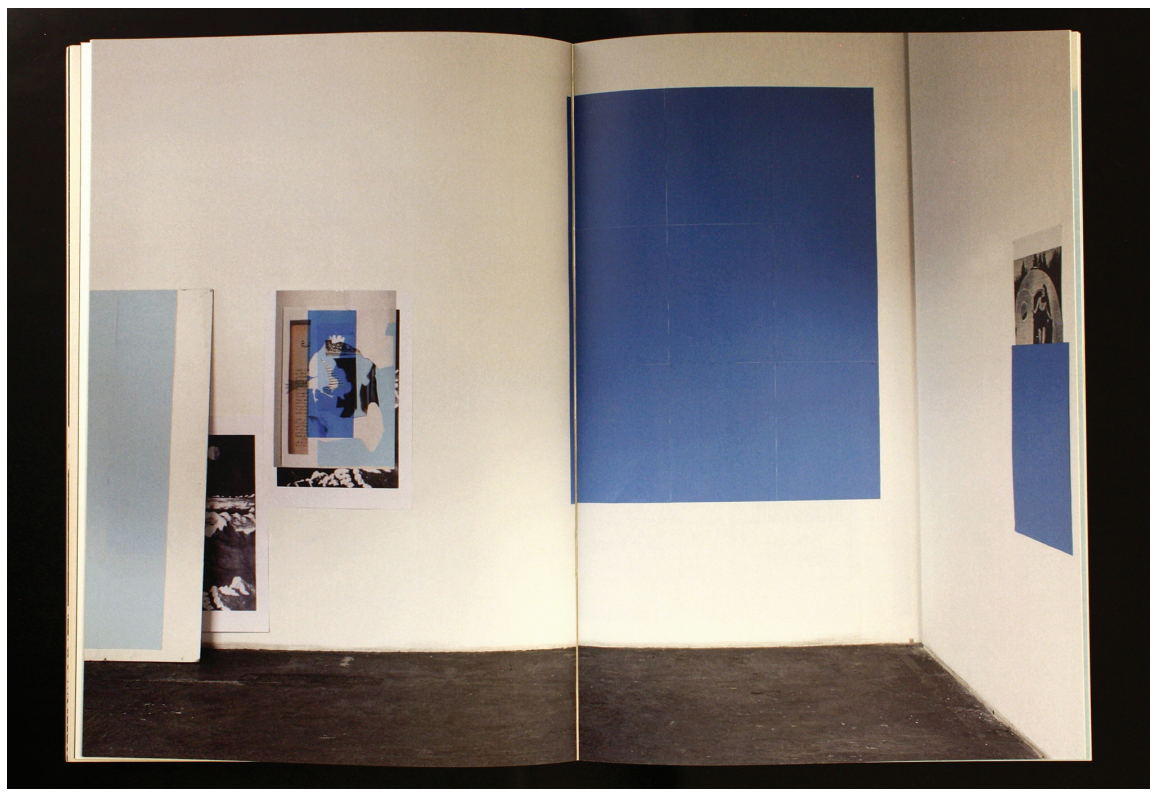

Figure 10: Installation view.

Source: Marwa Arsanios, Words as Silence, Language as Rhymes, 2012, $270 \times 190 \mathrm{~mm}$ (closed), n.p., (c) Marwa Arsanios. Courtesy of the artist.

an old speech, it is so empty [...]: all these papers are just good as material, not as something to be read and understood and discussed". ${ }^{74}$ Indeed, the collages and other visual elements included in the artist book also unfold in spatial installations as physical objects escaping from the book's pages (Figure 10), and the other artworks composing the Al-Hilal project transcend the textual form of language and investigate the other media that contributed to shaping and disseminating the rhetoric of modernist Egypt, like dance. ${ }^{75}$

Acknowledgements: I warmly thank Marwa Arsanios for our enlightening conversations about the Al-Hilal project, as well as Marc Lenormand for his helpful re-reading of this paper, and Mercedes Volait for her advice.

74 Arsanios/Atallah 2015.

75 See the video and performance Olga's Notes, All Those Restless Bodies (2014-2015), which take as their starting point an article in the January 1963 issue of Al-Hilal about Cairo's ballet school. 


\section{Sources}

Arsanios, Marwa (2012): Words as Silence, Language as Rhymes. Artist book published during a residency at the Jan van Eyck Academie, Maastricht.

Arsanios, Marwa/Atallah, Nadine (2015). Interview with Marwa Arsanios by the author at the artist's studio in Beirut (13 Sept. 2015). Unpublished.

Zaydan, Jurgi (ed.) (November 1957): Al-Hilal (The Crescent). Cairo: Dar al-Hilal.

Zaydan, Jurgi (ed.) (January 1958): Al-Hilal (The Crescent). Cairo: Dar al-Hilal.

\section{Bibliography}

Al-Atrash, Rasha (2012): "The Women of Al-Hilal in the 1950s and 1960s: A Bridge Between Two Fictions". In: Words as Silence, Language as Rhymes. Marwa Arsanios. N.p.

Al-Timawi, Ahmad Husayn (1992): Al-Hilal, mi'at 'am min al-tahdith wal-tanwir. 1892-1992

(Al-Hilal, one hundred years of modernism and enlightenment). Cairo: Dar al-Hilal.

Arsanios, Marwa/Fraisse, Geneviève (2014): “Conversation”. In: Suspended Spaces $n^{\circ} 3$. Inachever la Modernité. Edited by Suspended Spaces. Paris: Beaux-Arts de Paris Éditions, 278-291.

Barbaro, Ada (2013): La Fantascienza nella Letteratura Araba. Rome: Carocci Editore.

Bidoun Magazine (2014): “Round Table Three, The Future”. In: Here and Elsewhere. Edited by Massimiliano Gioni, Gary Carrion-Murayari, and Natalie Bell. New York City: New Museum, 145-151. Transcription of a round table moderated by Bidoun magazine that gathered Marwa Arsanios, Simone Fattal, GCC, Wafa Hourani, and Maha Maamoun.

Bier, Laura (2011): Revolutionary Womanhood: Feminisms, Modernity, and the State in Nasser's Egypt. Redwood City: Stanford University Press.

Bishop, Claire (2014): "Déjà Vu: La Citation et le Reformatage dans l’Art Contemporain”. In: Une Histoire. Art, architecture, design des années 1980 à nos jours. Edited by Christine Macel. Paris: Éditions du Centre Pompidou, Flammarion, 41-49.

Boym, Svetlana (2001): The Future of Nostalgia. New York City: Basic Books.

Boym, Svetlana (2010): “The Off-Modern Mirror”. e-flux Journal 19. http://www.e-flux.com/ journal/the-off-modern-mirror/ (11/28/2015).

Braidotti, Rosi (2009): "Learning from the Future”. Australian Feminist Studies 24.59: 3-9.

Caillet, Aline (2013): “Le Re-enactment: Refaire, Rejouer ou Répéter l'Histoire?”. Marges 17: 66-73. http://marges.revues.org/153 (12/20/2015).

Daoud, Hassan (2012): "Like Harsh Teachers When Reading the Writings of Our Literary Predecessors". In: Words as Silence, Language as Rhymes. Marwa Arsanios. N.p.

Dick, Philip K. (1995): “Le Pessimisme en Science Fiction”. In: Nouvelles, 1953-1963. Paris: Denoël.

Dhawan, Nikita (2013): On the Politics of Silence \& Speech. http://mixlr.com/98weeks/show reel/98weeks-on-the-politics-of-silence-and-speaking/ (11/28/2015). Recording of a talk at 98 week project space in Beirut as part of the project Our Lines Are Now Open. 
Dupont, Anne-Laure (2006): Ǧurğĩ Zaydān (1861-1914): Écrivain Réformiste et Témoin de la Renaissance Arabe. Beirut: Presses de l'Ifpo. New edition on line: http://books.openedi tion.org/ifpo/5454 (11/10/2015).

Fraisse, Geneviève (2012): La Fabrique du Féminisme. Congé-sur-Orne: Le Passager Clandestin. Ross, Christine (2013): The Past is the Present. It's the Future Too. The Temporal Turn in Contemporary Art. London: Continuum.

Vonarburg, Elisabeth (1994): "La Science-Fiction et les Héroïnes de la Modernité". Philosophiques XXI.2: 453-457. 